\title{
COVID-19'lu Hastalardaki Prognostik Faktörlerin Değerlendirilmesi: Pandemik Bir Merkez Olan Ankara Şehir Hastanesi Deneyimi
} Evaluation of Prognostic Factors in Patients with COVID-19:
Ankara City Hospital Experience as a Pandemic Center Emrah SALMAN, Nevreste ÇELIKKBILEK, Birsen ÖZDEM, Sibel GÖKAY, Sibel AYDOĞAN, Fisun KIRCA $\stackrel{2}{2},{ }^{2}$ Alparslan TOYRAN Reyhan BİLİCI SALMAN , Bedia DİÇ ${ }^{2}$

1 Ankara Şehir Hastanesi, Temel İmmünoloji, Ankara, Türkiye

2 Ankara Şehir Hastanesi, Tibbi Mikrobiyoloji, Ankara, Türkiye

3 Dışkapı Yıldırım Beyazıt Eğitim ve Araştırma Hastanesi, Romatoloji, Ankara, Türkiye

Yazışma Adresi

Correspondence Address

\section{Emrah SALMAN}

Ankara Şehir Hastanesi, Temel İmmünoloji, Ankara, Türkiye

emrahsalman85@hotmail.com

Geliş tarihi / Received : Ocak 27, 2021 Kabul tarihi / Accepted : Şubat 25, 2021 Elektronik yayın tarihi : Ocak 01, 2022 Online published

Bu makalede yapılacak atıf: Cite this article as:

Salman E, Çelikbilek N, Özdem B, Gökay S, Aydoğan S, Kırca F,

Toyran A, Bilici Salman R, Dinç B.

COVID-19'lu Hastalardaki

Prognostik Faktörlerin

Değerlendirilmesi: Pandemik Bir

Merkez Olan Ankara Şehir

Hastanesi Deneyimi.

Akd Tip D 2022; 8(1):9-15.

Emrah Salman

ORCID ID: 0000-0002-5293-0803 Nevreste Çelikbilek

ORCID ID: 0000-0001-6245-5383 Birsen Özdem

ORCID ID: 0000-0001-8714-7117 Sibel Gökay

ORCID ID: 0000-0002-8303-901X Sibel Aydoğan

ORCID ID: 0000-0001-8820-032X Fisun Kırca

ORCID ID: 0000-0003-0959-9091 Alparslan Toyran

ORCID ID: 0000-0002-0218-4881 Reyhan Bilici Salman

ORCID ID:0000-0002-2523-1695 Bedia Dinç

ORCID ID:0000-0001-8318-2556

\section{ÖZ}

Amaç:

Klinik serviste ve yoğun bakımda takip edilen COVID-19'lu hastalarda temel klinik karakteristikler ve laboratuvar indekslerini sistematik olarak analiz ederek erken dönemde hastalığın olası seyri hakkında ön görüde bulunabilmek amaçlandı.

\section{Gereç ve Yöntemler:}

Bu retrospektif, tek merkezli çalışma 1 Nisan ile 31 Mayıs 2020 tarihleri arasında Ankara Şehir Hastanesi'nde gerçekleştirilmiştir. Hastalar serviste ve yoğun bakımda takip edilen olmak üzere ikiye ayrıldı ve klinik veriler iki grup arasında karşılaştırıldı. Yoğun bakımdaki COVID-19 hastaları için bağımsız erken prediktörleri tanımlamak için tek değişkenli ve çok değişkenli lojistik regresyon analizi yapıldı. İnterlökin-6'nın yoğun bakımda yatışı öngörmesinde tanısal değerinin olup olmadığının belirlenebilmesi için ROC analizi yapıldı.

\section{Bulgular:}

Çok değişkenli lojistik regresyon analizine göre artan yaş (Odds oranı [OR] 1,1;\%95 güven aralığ1 [GA] 1,06-1,14; p<0,001), lenfosit sayısının düşüklüğü ( $O R=0,1 ; \% 95$ GA 0,03-0,30; $\mathrm{p}<0,001)$ ve yüksek interlökin 6 düzeyleri ( $\mathrm{OR}=1,01 ; \% 95$ GA 1.00-1,02; $<<0,001)$ bağımsız olarak yoğun bakımda yatan COVID-19'lu hastalarda önemli prediktörlerdendir. ROC eğrisinin altındaki alan 0,89 (\%95 GA 0,85-0,94; p<0,001), sınır değer $>19,85$ pg/ml olarak tespit edildi.

\section{Sonuç:}

İleri yaş, lenfopeni ve yüksek interlökin 6 düzeyleri olan erken COVID-19'lu hastalarda progresyon daha ileri olup bu hastalar daha çok yoğun bakımda izlenmektedir. Eğer bir hasta bu üç kriterden birine sahipse hastalık sürecinin sürveyansı ve yoğun bakım önceliği artmaktadır. Kritik hastaların erken tespiti, COVID-19 salgınıyla mücadelede işleri kolaylaştıracaktır.

Anahtar Sözcükler: COVID-19, SARS-CoV-2, Lenfopeni, İnterlökin-6, Tek değişkenli analiz, Çok değişkenli analiz

\section{ABSTRACT}

Objective:

Aim of the study was to analyze systematically the basic clinical characteristics and laboratory indexes in patients with COVID-19 followed in clinical service and intensive care, and to predict the possible course of the disease in the early period. 


\section{Methods:}

This retrospective, single-center study was conducted between April 1 and May 31, 2020 at Ankara City Hospital. The patients were divided into two groups: one received ordinary care, the other intensive therapy, and the clinical data were compared between the two groups. Univariate and multivariate logistic regression analysis were performed to identify independent early predictors for COVID-19 in patients independently hospitalized in intensive care. ROC analysis was performed to determine whether interleukin-6 has a diagnostic value in predicting hospitalization in intensive care.

\section{Results:}

Multivariable logistic regression analysis found that increasing age (adjusted odds ratio [OR], 1,1; 95\% confidence interval [CI]; 1,06-1,14; $\mathrm{p}<0,001$ ), lymphopenia (OR, 0,1; $95 \%$ CI: $0,03-0,30 ; \mathrm{p}<0,001)$ and high levels of interleukin-6 (OR, 1,$01 ; 95 \%$ CI: $1,00-1,02 ; p<0,001)$ were the important predictors of COVID-19 independently hospitalized in intensive care. The area under ROC curve of interleukin-6 was 0,89 [95\% CI $0,85-0,94 ; \mathrm{p}<0,001]$ and cut-off value was $>19,85 \mathrm{pg} / \mathrm{ml}$.

\section{Conclusion:}

Progression is more advanced in patients with early COVID-19 with increasing age, lymphopenia and high interleukin 6 levels, and these patients are mostly followed in intensive care. If a patient has one of these three criteria, surveillance of the disease process and intensive care priority increases. Early identification of critical patients will make things easier in tackling the COVID-19 outbreak.

Key Words: COVID-19, SARS-CoV-2, Lymphopenia, Interleukin-6, Univariate analysis, Multivariate analysis

\section{GİRIŞ}

Koronavirüsler zarflı, pozitif polariteli, tek iplikli RNA virüsleridir (1). Aralık 2019 tarihinde Çin'in Wuhan kentinde kökeni bilinmeyen pnömoni olgularının saptanmasından kısa süre sonra etkenin yeni bir koronavirüs olduğu saptanmış ve Dünya Sağlık Örgütü (DSÖ) hastalığa "coronavirus disease-2019 (COVID -19)" adını vermiştir. Kısa süre sonra virüsün adı "severe acute respiratory syndrome coronavirus-2 (SARS-CoV-2)" olarak tanımlandı (2,3). SARS-CoV-2 özellikle de yaşlı ve komorbiditeleri (diyabet, obezite, kronik böbrek yetmezliği, hipertansiyon ve kardiyovasküler hastalık) olan hastalarda önemli akciğer inflamasyonu, akut respiratuar distres sendromu (ARDS), kardiyak ve renal hasara yol açmaktadır. SARS-CoV-2'ye karşı efektif bir immun yanıt COVID-19'ün rezolüsyonunda önemlidir. Bununla birlikte, bazı çalışmalar hastalığın şiddeti ile dolaşımdaki proinflamatuar sitokinler ve immün sistemin hücreleri arasında önemli bir ilişki olduğunu gösterdi (4). Virüs yayılımı ve viral replikasyonun sinırlanması, inflamasyon ve enfekte hücrelerin temizlenmesi için çeşitli proinflamatuar sitokinlerin yapımı ve $\mathrm{CD} 4 / \mathrm{CD} 8+\mathrm{T}$ hücrelerin aktivasyonunu kapsayan antiviral tepkiler önemlidir $(5,6)$.
Virüs tarafindan olușturulan doku hasarı proinflamatuar granülositler ve makrofajların da katılımıla interlökin 6 (IL-6) gibi proinflamatuar sitokinlerin aşırı artışına yol açar. $\mathrm{Bu}$ durum makrofaj aktivasyon sendromu veya sekonder hemofagositik lenfohistiyositoz olarak da adlandırılan sitokin firtınasına neden olur (7). Vasküler permeabilite artışı, çoklu organ yetmezliği ve ölüm için artmış riskler ile karakterizedir. C-reaktif protein (CRP) hem akut hem de kronik inflamasyonda yaygin olarak kullanilan inflamasyon belirteçlerindendir. Serum CRP düzeyleri inflamasyon ve doku hasarını gösteren çeşitli hastalıkların seyri sırasında artabilmektedir (8).

Çalışmanın amacı klinik serviste ve yoğun bakımda takip edilen COVID-19'lu hastalarda temel klinik karakteristikler ve laboratuvar indekslerini sistematik olarak analiz ederek erken dönemde hastalığın olası seyri hakkında ön görüde bulunabilmektir.

\section{GEREÇ ve YÖNTEMLER}

Bu retrospektif, tek merkezli çalışma 1 Nisan ile 31 Mayıs 2020 tarihleri arasında Ankara Şehir Hastanesi'nde gerçekleştirildi. Çalışmamıza COVID-19 tanısı almış, oksijen desteği olmadan sadece gözlem amaçlı serviste yatan ve yoğun bakıma alınmayan 300 hasta ve oksijen desteği olan ve yoğun bakıma alınan 66 hasta alındı. Laboratuvar testleri tüm hastalar için hastanemize başvuru sırasında alınan ilk PCR testi pozitifliğinden sonra alınan numunelerin sonucudur.

Hastaneye başvuruları sırasında alınan nazofarengeal ve orofarengeal örneklerinde SARS-CoV-2 polimeraz zincir reaksiyon (PCR) testleri pozitif bulunan 366 yatan hasta bu çalışmaya dahil edilmiştir. IL-6 düzeyleri istenmemiş olan hastalar, hospitalizasyon sırasinda akut miyokard enfarktüsü geçiren hastalar, PCR konfirmasyonu olmayip da klinik olarak COVID-19 tanısı konan hastalar çalışmaya dahil edilmemiştir. Veriler elektronik hasta kayıtlarından retrospektif olarak elde edildi. Çalışma protokolü Ankara Şehir Hastanesi etik kurulunca onaylanmıştır (E1-20-776). Araştırma yayın etiğine ve Helsinki Deklerasyonuna uygun olarak gerçekleştirildi.

Çalışma, T.C. Sağlık Bakanlığı Sağlık Hizmetleri Genel Müdürlüğü Bilimsel Çalışma Platformu aracıllğıyla onaylandı (Tarih: 19.05.2020 ve Karar No: Emrah Salman 2020-05-17T19_36_58.xml).

Nazofarengeal ve orofarengeal örneklerde SARS-CoV-2 saptanması Real Time Revers Transkriptaz Polimeraz Zincir Reaksiyonu (RT-PCR) metodu ile RNA bağımlı RNA polimeraz (RdRp) genini hedef alarak gerçekleştirildi. Steril rayon veya dakron uçlu eküvyon çubuğu nazofarengeal ve orofarengeal örnekleri almak için kullanıldı. Örnek alımı tamamlandıktan sonra eküvyon uçları 2 ml'lik steril viral taşıma besiyerine aktarıldı. Örnek alımından en geç 12 saat içerisinde örnekler moleküler viroloji laboratuvarına ulaştırıldı. RNA izolasyonu Bi-Speedy viral nükleik asit izolasyon kitiyle (Bioeksen, İstanbul, Türkiye) üreticinin talimatları doğrultusunda gerçekleştirildi. PCR işlemi Bio-Speedy COVID-19 RT-qPCR saptama kiti ( Bioeksen, İstanbul, Türkiye) ile Rotor-Gene Q cihazında (Qiagen, 
COVID-19'lu Hastalardaki Prognostik Faktörlerin Değerlendirilmesi: Pandemik Bir Merkez Olan Ankara Şehir Hast. Deneyimi

Hilden, Almanya) gerçekleștirildi. Eșik döngü sayıları $(\mathrm{Ct})$ 40 'dan az olanlar pozitif olarak değerlendirildi. CRP düzeyi (normal değeri $<0,005 \mathrm{~g} / \mathrm{L}$ ) BNII nefelometre cihazı (Siemens, Erlangen, Almanya) ile ölçüldü. IL-6 düzeyi (normal değeri $<3,4 \mathrm{pg} / \mathrm{mL}$ ) elektrokemilüminesans yöntemi ile Immulite 2000 cihazı (Siemens, Erlangen, Almanya) ile ölçüldü. Sistemik immun-inflamasyon indeksi nötrofil ve platelet sayısının çarpımının lenfosit sayısına oranlanmasıyla saptanmaktadır ve hücrelerin düzeyi Siemens Advia 2120i cihazı (Siemens, Erlangen, Almanya) ile ölçüldü.

İstatistiksel değerlendirme Statistical Package for Social Sciences (SPSS) for Windows 22.0 (IBM SPSS Inc., Chicago, IL) programı kullanılarak yapıldı. Verilerin normal dağılımı Kolmogorov-Smirnov testi ile değerlendirildi. Sayısal değişkenlerden normal dağılım sergileyenler ortalama \pm standart sapma olarak, normal dağılım sergilemeyenler ortanca (medyan) olarak gösterildi. Kategorik değişkenler sayı ve yüzde olarak belirtildi.

İki grup karşılaştırmalarında normal dağılım sergileyen sayısal değişkenlerin analizinde bağımsız örneklemler için t-testi ve normal dağılım sergilemeyen sayısal değişkenlerin analizinde Mann-Whitney $U$ testi tercih edildi. Kategorik verilerin karşılaştırılmasında ise Ki-kare testi ve Fisher'in kesin Ki-kare testi kullanıldı. İki grup arasındaki istatistiksel açıdan anlamlı demografik ve laboratuvar veriler tek değişkenli lojistik regresyon analizi ile değerlendirildi. Tek değişkenli lojistik regresyon analizinde istatistiksel açıdan anlamlı olan veriler çok değişkenli lojistik regresyon analizi ile değerlendirildi. Çoklu regresyon analizinde backward LR yapılmıștır. İnterlökin-6'nın yoğun bakım hastalarının öngörülmesinde tanısal karar verdirici özellikleri ROC (Receiver Operating Characteristics) eğrisi analizi ile incelendi. İstatistiksel analizlerde $\mathrm{p}<0.05$ değeri anlaml kabul edildi.

\section{BULGULAR}

Çalışmaya alınan hastaların 203'ü $(\% 55,5)$ erkek hastalardı. Hastaların yaş ortalaması 45,9 idi.

Klinik serviste yatan hastaların yaş ortalaması 40,6 iken yoğun bakımda yatan hastaların yaş ortalaması 70'ti. (p $<0,001)$. Yoğun bakımdaki hastaların 36's1 entübe olup bunlardan da 30'u vefat etmiştir. Sigara kullanan hasta sayısı 31 'di $(\% 8,5)$. En çok görülen komorbidite $\% 12,8$ ile hipertansiyon(HT) iken diyabetes mellitus(DM) \%3,8, koroner arter hastalığı(KAH) $\% 1,9$, kronik obstrüktif akciğer hastlalığı(KOAH) \%1,4, kronik böbrek hastalığı $(\mathrm{KBH}) \%$ 1,6 ve astım \%1,9'du. İleri yaş, sigara kullanımı, nötrofil sayısının yüksekliği, lenfosit sayısının düşüklüğü, nötrofil lenfosit oranının (NLR) yüksekliği, CRP'nin yüksekliği, IL-6'nın yüksekliği , ferritinin yüksekliği, albüminin yüksekliği, prokalsitoninin yüksekliği, D-dimerin yüksekliği, LDH'nın yüksekliği, fibrinojenin yüksekliği, protrombin zamanının yüksekliği ve AST'nin yüksekliği yoğun bakımda yatan hastalarda istatistiksel olarak anlamliydı ( $\mathrm{p}<0,001$; 0,$03 ;<0,001 ;<0,001 ;<0,001 ;<0,001 ;<0,001 ;<0,001$; $<0,001 ;<0,001 ;<0,001 ;<0,001 ;<0,001 ;<0,001 ;<0,001)$ ayrıca platelet sayısının yüksekliği istatistiksel olarak anlamlı değildi $(\mathrm{p}=0,16)$ (Tablo I).
Tablo I. COVID-19'lu hastaların hastaneye başvuru sırasındaki demografik ve laboratuvar bulguları

\begin{tabular}{|c|c|c|c|}
\hline & $\begin{array}{l}\text { Serviste yatan hastalar } \\
\text { n=300 } \\
\text { Ort. } \pm \text { s.s./Medyan/n\% }\end{array}$ & $\begin{array}{l}\text { Yoğun bakımda yatan } \\
\text { hastalar } \\
\text { n=66 } \\
\text { Ort. } \pm \text { s.s. } / \text { Medyan } / \mathrm{n} \%\end{array}$ & $\mathbf{p}$ \\
\hline Yaş, yil & $40,6 \pm 17,9$ & $70 \pm 12,3$ & $<0,001^{\top}$ \\
\hline $\begin{array}{lr}\text { Yaş grubu } & \\
1-19 & \% 7,9 \\
20-29 & \% 15,3 \\
30-49 & \% 35,5 \\
50-59 & \% 13,4 \\
60-80 & \% 23,5 \\
>80 & \% 4,4\end{array}$ & & & \\
\hline $\begin{array}{l}\text { Cinsiyet } \\
\text { Kadın }\end{array}$ & $140(\% 46,7)$ & $23(\% 34,8)$ & $0,08^{\mathrm{X} 2}$ \\
\hline Sigara kullanımı & $21(\% 7)$ & $10(\% 15,2)$ & $0,03^{x^{2}}$ \\
\hline $\begin{array}{l}\text { Beyaz küre sayısı, } \\
\text { x10 }^{9} / \mathrm{L}\end{array}$ & $5,32(4,20-6,46)$ & $6,84(5,07-10,11)$ & $<0,001^{\mathrm{m}}$ \\
\hline $\begin{array}{l}\text { Nötrofil sayıst, } \\
\times 10^{9} / \mathrm{L}\end{array}$ & $2,96(2,17-4,13)$ & $5,00(3,14-7,92)$ & $<0,001^{\mathrm{m}}$ \\
\hline $\begin{array}{l}\text { Lenfosit sayist, } \\
\times 10^{9} / \mathrm{L}\end{array}$ & $1,49(1,05-1,90)$ & $0,72(0,46-1,02)$ & $<0,001^{\mathrm{m}}$ \\
\hline NLR & $2,02(1,30-3,31)$ & $7,88(4,79-11,38)$ & $<0,001^{\mathrm{m}}$ \\
\hline $\begin{array}{l}\text { Platelet sayısı, } \\
\text { x10//L }\end{array}$ & $231(184-282)$ & $206(140,75-290)$ & $0,16^{\mathrm{m}}$ \\
\hline SII & $462,8(295,1-806,1)$ & $1761,2(976,5-3089,2)$ & $<0,001^{\mathrm{m}}$ \\
\hline CRP, mg/L & $6,14(1,65-27,4)$ & $110,5(49,12-173,75)$ & $<0,001^{\mathrm{m}}$ \\
\hline IL-6, pg/mL & $7,28(3,90-14,75)$ & $62,40(34,72-151,75)$ & $<0,001^{\mathrm{m}}$ \\
\hline Ferritin, $\mu \mathrm{g} / \mathrm{L}$ & $108(33,8-229,77)$ & $450(202,55-874,9)$ & $<0,001^{\mathrm{m}}$ \\
\hline Albümin, $\mathrm{g} / \mathrm{L}$ & $44(41-46)$ & $35(30,25-40,4)$ & $<0,001^{\mathrm{m}}$ \\
\hline $\begin{array}{l}\text { Prokalsitonin, } \\
\mu \mathrm{g} / \mathrm{L}\end{array}$ & $0,03(0,03-0,05)$ & $0,21(0,06-0,76)$ & $<0,001^{\mathrm{m}}$ \\
\hline D-dimer, mg/L & $0,35(0,19-0,64)$ & $1,5(0,30-4,43)$ & $<0,001^{\mathrm{m}}$ \\
\hline LDH, U/L & $214(179-264,7)$ & $356(218-486,5)$ & $<0,001^{\mathrm{m}}$ \\
\hline Fibrinojen, $\mathrm{g} / \mathrm{L}$ & $3,18(2,54-4,07)$ & $4,58(3,72-5,73)$ & $<0,001^{\mathrm{m}}$ \\
\hline $\begin{array}{l}\text { Protrombin } \\
\text { zamanı, sn }\end{array}$ & $12,2(11,6-12,83)$ & $13,5(12,4-15,2)$ & $<0,001^{\mathrm{m}}$ \\
\hline ALT, U/L & $23(17-36)$ & $28(17,5-49,5)$ & $0,067^{\mathrm{m}}$ \\
\hline$\overline{A S T}, \mathrm{U} / \mathrm{L}$ & $21(16-30)$ & $45(25,5-104,8)$ & $<0,001^{\mathrm{m}}$ \\
\hline
\end{tabular}

Klinik serviste yatan hastalarda lenfopeni görülme oranı $\% 11$ iken yoğun bakım hastalarında lenfopeni görülme oranı \%86,3'tü. Klinik serviste yatan hastalarda trombositopeni görülme oranı \%10 iken yoğun bakım hastalarında trombositopeni görülme oranı \%30,3'tü.

$\mathrm{Bu}$ iki grup komorbidite açısından karşılaştırıldığında; HT varlığı yoğun bakım hastalarında \%33,3 $(\mathrm{n}=22)$ ile daha yüksek olup, fark istatistiksel olarak anlamlı bulunmuştur $(\mathrm{p}<0,01)$. DM varlığı yoğun bakım hastalarında \%9,1 $(\mathrm{n}=6)$ ile daha yüksek olup, fark istatistiksel olarak anlamlı bulunmuştur $(\mathrm{p}<0,01)$. KOAH varlığı yoğun bakım hastalarında $\% 6,1(\mathrm{n}=4)$ ile daha yüksek olup, fark istatistiksel olarak anlamlı bulunmuştur $(\mathrm{p}=0,004)$. KBH varlığ1 yoğun bakım hastalarında $\% 6,1(n=4)$ ile daha yüksek olup, fark istatistiksel olarak anlamlı bulunmuştur $(\mathrm{p}=0,01)$. Bu iki grup arasında yoğun bakım hastalarında astım varlığı $(\% 14,3)$ daha yüksek saptanmakla birlikte, aradaki fark istatistiksel olarak anlamlı 
Salman E. ve ark.

bulunmamıştır $(p=0,63)$ ayrıca yoğun bakım hastalarında KAH varlığı (\%3) daha yüksek saptanmakla birlikte, aradaki fark istatistiksel olarak anlamlı bulunmamıştır $(\mathrm{p}=0,61)$ (Tablo II).

Tablo II. COVID-19'lu hastaların komorbidite durumları

\begin{tabular}{lccc}
\hline & $\begin{array}{c}\text { Serviste yatan hastalar } \\
\mathbf{n}(\%)\end{array}$ & $\begin{array}{c}\text { Yoğun bakımda } \\
\text { yatan hastalar } \\
\mathbf{n}(\%)\end{array}$ & $\mathbf{p}$ \\
\hline Ek hastalık varlığı & $41(\% 13,7)$ & $31(\% 47)$ & $<0,001$ \\
\hline HT varlı̆̆ & $25(\% 8,3)$ & $22(\% 33,3)$ & $<0,001$ \\
\hline DM varlı̆̆ & $8(\% 2,7)$ & $6(\% 9,1)$ & $<0,001$ \\
\hline KAH varlı̆ı & $5(\% 1,7)$ & $2(\% 3)$ & 0,61 \\
\hline KOAH varlığ & $1(\% 0,3)$ & $4(\% 6,1)$ & 0,004 \\
\hline KBH varlı̆̆ & $2(\% 0,7)$ & $4(\% 6,1)$ & 0,01 \\
\hline Astım varlığı & $6(\% 2)$ & $1(\% 14,3)$ & 0,63 \\
\hline
\end{tabular}

COVID-19 tanısı almış hastaların hastalığını ağır seyretmesi için olası prediktörleri ön görmek için lojistik regresyon analizi yapıldı. Çok değişkenli lojistik regresyon analizine göre artan yaş (Odds oranı [OR] 1,1;\%95 güven aralığı [GA] $1,06-1,14 ; \mathrm{p}<0,001)$, lenfosit sayısının düşüklüğü $(\mathrm{OR}=0,1$ ;\%95 GA 0,03-0,30; p<0,001) ve yüksek IL-6 düzeyleri (Odds oranı [OR] 1,01;\%95 güven aralığ1 [CI] 1.00-1,02); $\mathrm{p}<0,001$ bağımsız olarak yoğun bakımda yatan COVID-19'lu hastalarda önemli prediktörlerdendir (Tablo III).

Tablo III. COVID-19 hastalığı ile ilişkili risk faktörlerinin tek değişkenli ve çok değişkenli lojistik regresyon analizi

\begin{tabular}{|c|c|c|c|c|c|c|}
\hline & \multicolumn{3}{|c|}{ Tek değiskenli model } & \multicolumn{3}{|c|}{ Çok değiskenli model } \\
\hline & OR & $\begin{array}{l}\text { \%95 } \\
\text { güven } \\
\text { aralığ }\end{array}$ & p & OR & $\begin{array}{l}\text { \%95 güven } \\
\text { aralığı }\end{array}$ & p \\
\hline Yass, yll & 1,11 & $1,08-1,14$ & $<0,001$ & 1,10 & $1,06-1,14$ & $<0,001$ \\
\hline Sigara kullanımı & 2,37 & $1,06-5,31$ & 0,03 & & & \\
\hline $\begin{array}{l}\text { Beyaz küre sayısı, } \\
\text { x10 } / \text { L }\end{array}$ & 1,02 & $0,98-1,05$ & 0,212 & & & \\
\hline $\begin{array}{l}\text { Nötrofil } \\
\text { sayısı,x10 } 10^{9} / \mathrm{L}\end{array}$ & 1,26 & $1,15-1,38$ & $<0,001$ & & & \\
\hline $\begin{array}{l}\text { Lenfosit, } \\
\text { sayısı,x10 } 10^{9} / \mathrm{L}\end{array}$ & 0,04 & $0,01-0,10$ & $<0,001$ & 0,10 & $0,03-0,30$ & $<0,001$ \\
\hline NLR & 1,31 & $1,20-1,42$ & $<0,001$ & & & \\
\hline SII & 1,001 & $\begin{array}{l}1,001- \\
1,001\end{array}$ & $<0,001$ & & & \\
\hline CRP, mg/L & 1,02 & $1,01-1,02$ & $<0,001$ & & & \\
\hline IL-6, pg/mL & 1,02 & $1,01-1,03$ & $<0,001$ & 1,01 & $1,00-1,02$ & $<0,001$ \\
\hline Ferritin, $\mu \mathrm{g} / \mathrm{L}$ & 1,002 & $\begin{array}{l}1,002- \\
1,003\end{array}$ & $<0,001$ & & & \\
\hline Albümin, $g / \mathbf{L}$ & 0,75 & $0,70-0,80$ & $<0,001$ & & & \\
\hline Prokalsitonin, $\mu \mathrm{g} / \mathrm{L}$ & 1,59 & $1,17-2,14$ & 0,003 & & & \\
\hline D-dimer, $\mathrm{mg} / \mathrm{L}$ & 1,01 & $0,99-1,03$ & 0,212 & & & \\
\hline LDH, U/L & 1,00 & $\begin{array}{l}1,007- \\
1,012\end{array}$ & $<0,001$ & & & \\
\hline Fibrinojen, $\mathrm{g} / \mathrm{L}$ & 0,99 & $0,98-1,01$ & 0,802 & & & \\
\hline $\begin{array}{l}\text { Protrombin } \\
\text { zamanı, sn }\end{array}$ & 1,01 & $0,98-1,05$ & 0,244 & & & \\
\hline AST, U/L & 1,02 & $1,01-1,03$ & $<0,001$ & & & \\
\hline Ek hastalık & 5,59 & $3,11-10,04$ & $<0,001$ & & & \\
\hline HT & 5,50 & $2,85-10,59$ & $<0,001$ & & & \\
\hline DM & 3,65 & $1,22-10,90$ & 0,02 & & & \\
\hline КОАН & 19,29 & $\begin{array}{l}2,12- \\
175,54 \\
\end{array}$ & 0,009 & & & \\
\hline KBH & 9,61 & $1,72-53,64$ & 0,01 & & & \\
\hline
\end{tabular}

Kısaltma: OR, tahmini rölatif risk
İnterlökin-6'nın yoğun bakıma yatışın öngörülmesinde tanısal değerinin olup olmadığının belirlenebilmesi için ROC analizi yapıldı. ROC eğrisinin altındaki alan 0,89 (\%95 güven aralığ $10,85-0,94 ; p<0,001)$, sinır değer 19,85 olarak tespit edildi. Bu sınır değerinde IL-6'nın yoğun bakıma yatışın öngörülmesinde $\% 87,9$ sensitivite, $\% 81,3$ spesifiteye sahip olduğu görüldü (Şekil 1).

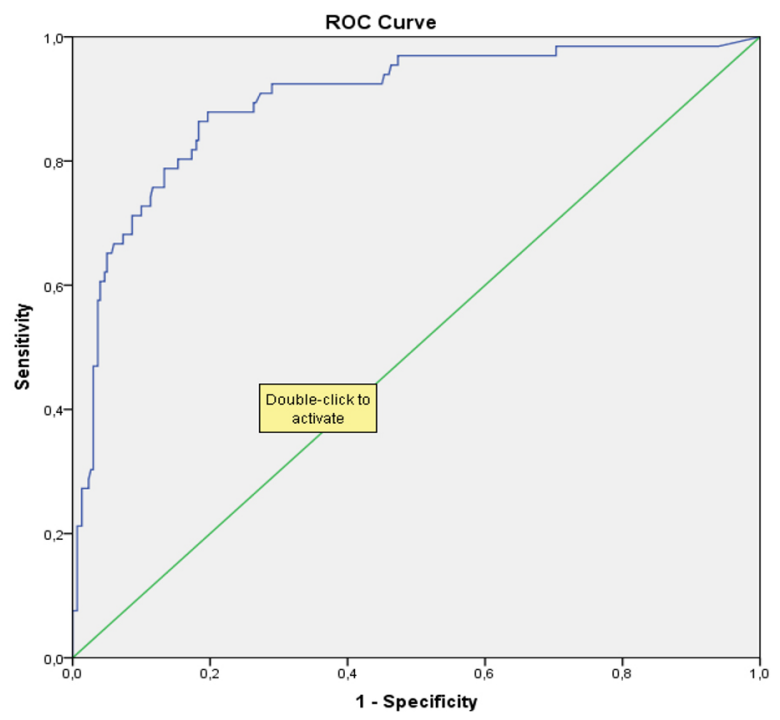

Şekil 1. Yoğun bakıma yatan hastalarda IL-6 düzeylerinin ROC eğrisi

\section{TARTIŞMA}

COVID-19'lu hastaların eksponansiyel olarak artışı salgının yoğun olarak seyrettiği ülkelerde sağlık sistemlerine ağır bir yük getirmektedir. Ülkemiz gibi pandeminin ağır seyrettiği ülkelerde COVID-19 mortalitesini azaltmak için akılcı triyaj yapılmasına ihtiyaç vardır. Sonuçta erken evrede klinisyenlere hastalığın ağırlığı hakkında prediktörler sunmak önemlidir. $\mathrm{Bu}$ retrospektif kohort çalışmasında, yoğun bakımda yatan COVID-19'lu hastalar için bağımsız risk faktörleri ileri yaş, lenfopeni ve yüksek IL-6 düzeyleri olarak belirlendi. İleri yaş için geriatrik yaş sınırı olan 65 yaş ve sonrası kabul edilmiştir.

Önceki pek çok çalışmada COVID-19'lu hastalarda ileri yaşın genç ve orta yaşa göre daha ağır seyrettiği ve mortaliteye yol açtığı bildirilmiştir (9-12). Çalışmamızın sonuçları ileri yaşın yoğun bakımda yatan COVID-19'lu hastalar için bağımsız bir risk faktörü olduğunu ayrıca doğrulamıştır. İmmünitenin zayıflaması ve visseral organların kompensatuvar fonksiyonlarının azalması SARS-CoV-2 enfeksiyonu sonrasında neden ağır COVID-19 hastalığına eğilim olmasının nedenlerinden biridir.

Bizim sonuçlarımıza göre lenfopeni hastalığın ağır seyretmesi ile ilişkilidir. Çin'de yapılan bir çalışmada COVID-19'lu hastalarda akut akciğer hasarının şiddeti ve lenfopeni arasında korelasyon saptanmıştır (21). CD4+ ve CD8+ kaynaklı lenfopeni SARS $(13,14)$, MERS $(15)$ ve respiratuar sinsityal virüs (16) çeşitli viral enfeksiyonlarda saptanmıştır. Bir çalışmada SARS'ta meydana gelen lenfopeninin artmış çözünür vasküler hücre adezyon molekülü-1 (VCAM-1) nedeniyle meydana gelen artmış vasküler geçirgenlikten 
COVID-19’lu Hastalardaki Prognostik Faktörlerin Değerlendirilmesi: Pandemik Bir Merkez Olan Ankara Şehir Hast. Deneyimi

kaynaklandığı bildirilmiştir (17) ayrıca proptozis (18), T lenfositin üzerine direkt bir sitopatik virüs etkisi (19) veya sitokin firtınasına bağlı bir kemik iliği supresyonu (20) hipotezleri mevcuttur. Bütün bu verilere rağmen COVID-19'lu hastalarda kesin mekanizma henüz net değildir.

IL-6 akciğer parankiminde alveolar makrofajlar, tip II pnömositler, T lenfositler ve akciğer fibroblastlarını da içeren çeşitli hücrelerde sentezlenir.IL-6 immünolojik ve inflamatuar yanıtları regüle eden önemli bir sitokindir (22).

IL-6 akciğerlerin inflamasyon durumunu yansitan bir akut faz reaktanı olup klinik ve deneysel çalışmalarda sepsis ve çeşitli akut organ hasaralarında prognostik bir belirteç olduğu gösterilmiştir. IL-6'nın plazma ve/veya bronkoalveolar düzeyleri akciğer hasarında erken bir biyobelirteç olarak kullanılır. Uzamış mekanik ventilasyon, organ disfonksiyonları, morbidite ve mortalite ile ilişkili bulunmuştur $(23,24)$. IL-6 enfeksiyonlara ve doku hasaralarına karşı konak savunmasına katkıda bulunur fakat SARS-CoV-2 'ye karş1 yanıtta aşırı ve kontrolsüz salınımı akut ağır sistemik bir inflamatuar yanıt olan sitokin firtınasına yol açar. Hospitalize COVID-19'lu hastalar arasında yapılan bir dizi çalışmada başvuru sırasındaki yüksek IL-6 düzeyleri, mekanik ventilasyon ve yoğun bakımda takip gibi ağır hastalığa yol açma için artmış risk göstermişlerdir ayrıca bu hastalarda akut respiratuar distres sendromu (ARDS) ve çoklu organ yetmezliklerde de artış gözlenmiştir $(25,26)$.

ROC eğrinin altındaki alan IL-6 için 0,89 olarak tespit edildi ve bulunan değer yüksek bir tanısal ayırt ediciliği işaret etmektedir. Ayrıca IL-6'nın 19,85pg/ml sınır değeri için tanısal sensitivitesinin \%87,9 ve spesifitesinin \%81,3 olmasına dikkat çekmek gerekir. Bu noktadan hareketle IL-6 değeri $>19,85$ pg/ml olan hastaların büyük olasılıkla yoğun bakıma yatış gerektireceği sonucu çıkmaktadır.

\section{ÇALIŞMANIN KISITLILIKLARI}

Çalışmada çeşitli kısıtlılıklar mevcuttur. Bu çalışma tek merkezli ve retrospektiftir. Göreceli olarak düşük sayıda hasta ile yapıldığı için klinik serviste yatan ve yoğun bakımda yatan hastalardaki sürekli değişkenler arasındaki ilişki Mann-Whitney U testi ile yapılmıştır ve analizin istatistiksel gücünü azaltmıştır. Çalışmada hasta verileri elektronik kayıt sisteminden retrospektif olarak alındığı ve vücut kitle indeksleri yer almadığı için obezite açısından bir değerlendirme yapılamamıştır. Tedavi sonrasındaki parametrelere bakılmamıştır. Ayrıca erken prediktörlerin güvenirliğini doğrulamak için prospektif kohort çalışmalarına ihtiyaç vardır bu sayede gelecekte yeni prediktif bir model veya skorlama kriteleri getirilebilir. Diğer bir kısıtlılık ise kantitatif viral RNA saptanmasının eksikliğidir.

\section{SONUÇ}

İleri yaş, lenfopeni ve yüksek IL-6 düzeyleri olan erken COVID-19'lu hastalarda progresyon daha ileri olup bu hastalar daha çok yoğun bakımda izlenmektedir. Eğer bir hasta bu üç kriterden birine sahipse hastalık sürecinin sürveyansı ve yoğun bakım önceliği artmaktadır. Kritik hastaların erken tanınması COVID-19 salgını ile mücadelede işleri kolaylaştıracaktır. Ayrıca daha kapsamlı, çok merkezli prospektif çalışmalara ihtiyaç söz konusudur.

Etik Komite Onayı: Bu araştırma, ilgili tüm ulusal düzenlemelere, kurumsal politikalara ve Helsinki Bildirgesinin ilkelerine uygundur ve Ankara Şehir Hastanesi Etik kurulu tarafindan onaylanmıştır (Onay numarası (E1-20-776).

Hasta onamı: Çalışma retrospektif olduğu için aydınlatılıış onam formu doldurulmamıştır.

Yazar katkıları: Fikir-E.S, B.Ö, F.K;

Tasarım-E.S,S.A; Denetleme-E.S, N.Ç, B.D; Kaynaklar-B.D; Malzemeler-E.S; Veri toplanması ve/veya İşlemesi-E.S, A.T, R.BS; Analiz ve/veya Yorum-R.BS; Literatür taranması-S.G, F.K; Yazıyı Yazan-E.S, R.BS; Eleştirel İnceleme-N.Ç, B.D.

Çıkar çatışması: Yazarların beyan edecek çıkar çatışması yoktur.

Finansal destek: Yazarlar bu çalışma için finansal destek almadıklarını beyan etmişlerdir. 


\section{KAYNAKLAR}

1. Weiss SR, Leibowitz JL. Coronavirus pathogenesis. Adv Virus Res 2011; 81: 85-164.

2. Hui DS, I Azhar E, Madani TA, Ntoumi F, Kock R, Dar O, Ippolito G, Mchugh TD, Memish ZA, Drosten C, Zumla A, Petersen E. The continuing 2019-nCoV epidemic threat of novel coronaviruses to global health The latest 2019 novel coronavirus outbreak in Wuhan, China. Int J Infect Dis 2020; 91: 264-6.

3. Lu R, Zhao X, Li J, Niu P, Yang B, Wu H, Wang W, Song H, Huang B, Zhu N, Bi Y, Ma X, Zhan F, Wang L,Hu T, Zhou H, Hu Z, Zhou W, Zhao L, Chen J, Meng Y, Wang J, Lin Y, Yuan J, Xie Z, Ma J, Liu WJ, Wang D, Xu W, Holmes EC, Gao GF, Wu G, Chen W, Shi W, Tan W. Genomic characterisation and epidemiology of 2019 novel coronavirus: implications for virus origins and receptor binding. The Lancet 2020; 395: 565-74.

4. Wan S, Yi Q, Fan S, Lv J, Zhang X, Guo L, Lang C, Xiao Q, Xiao K, Yi Z, Qiang M, Xiang J, Zhang B, Chen Y. Characteristics of lymphocyte subsets and cytokines in peripheral blood of 123 hospitalized patients with 2019 novel coronavirus pneumonia (NCP). MedRxiv, 2020.

5. Ivashkiv LB, Donlin LT. Regulation of type I interferon responses. Nature reviews Immunology 2014; 14: 36-49.

6. Li G, Fan Y, Lai Y, Han T, Li Z, Zhou P, Pan P, Wang W, Hu D, Liu X, Zhang Q, Wu J. Coronavirus infections and immune responses. J Med Virol 2020; 92: 424-32.

7. George, M R. Hemophagocytic lymphohistiocytosis: review of etiologies and management. Journal of blood medicine 2014; 5: 69.

8. Meduri, G., Kohler G, Headley S, Tolley E, Stentz F, Postlethwaite A. Inflammatory cytokines

in the BAL of patients with ARDS. Persistent elevation over time predicts poor outcome.Chest 1995; 8: 1303-14.

9. Chen N, Zhou M, Dong X, Qu J, Gong F, Han Y, Qiu Y, Wang J, Liu Y, Wei Y, Xia J, Yu T, Zhang X, Zhang L. Epidemiological and clinical characteristics of 99 cases of 2019 novel coronavirus pneumonia in Wuhan, China: a descriptive study. . The Lancet 2020; 395: 507-13.

10. Guan WJ, Ni ZY, Hu Y, Liang WH, Ou CQ, He JX, Liu L, Shan H, Lei CL, Hui DSC, Du B, Li LJ, Zeng G, Yuen KY, Chen RC, Tang CL, Wang T, Chen PY, Xiang J, Li SY, Wang JL, Liang ZJ, Peng YX, Wei L, Liu Y, Hu YH, Peng P, Wang JM, Liu JY, Chen Z, Li G, Zheng ZJ, Qiu SQ, Luo J, Ye CJ, Zhu SY, Zhong NS; China Medical Treatment Expert Group for Covid-19. Clinical Characteristics of Coronavirus Disease 2019 in China. N Engl J Med 2020; 382 : 1708-20.
11. Wang X, Fang J, Zhu Y, Chen L, Ding F, Zhou R, Ge L, Wang F, Chen Q, Zhang Y, Zhao Q. Clinical characteristics of non-critically ill patients with novel coronavirus infection (COVID-19) in a Fangcang Hospital. Clin Microbiol Infect 2020; 26: 1063-106.

12. Ji D, Zhang D, Xu J, Chen Z, Yang T, Zhao P, Chen G, Cheng G, Wang Y, Bi J, Tan L, Lau G, Qin E. Prediction for Progression Risk in Patients With COVID-19 Pneumonia: The CALL Score. Clin Infect Dis 2020; 71: 1393-9.

13. He Z, Zhao C, Dong Q, Zhuang H, Song S, Peng G, Dwyer DE. Effects of severe acute respiratory syndrome (SARS) coronavirus infection on peripheral blood lymphocytes and their subsets. Int J Infect Dis 2005; 9: 323-30.

14. Booth CM, Matukas LM, Tomlinson GA, Rachlis AR, Rose DB, Dwosh HA, Walmsley SL, Mazzulli T, Avendano M, Derkach P, Ephtimios IE, Kitai I, Mederski BD, Shadowitz SB, Gold WL, Hawryluck LA, Rea E, Chenkin JS, Cescon DW, Poutanen SM, Detsky AS. Clinical features and short-term outcomes of 144 patients with SARS in the greater Toronto area. JAMA 2003;289: 2801-9.

15. Yang YM, Hsu CY, Lai CC, Yen MF, Wikramaratna PS, Chen HH, Wang TH. Impact of Comorbidity on Fatality Rate of Patients with Middle East Respiratory Syndrome. Sci Rep 2017; 7: 11307.

16. O'Donnell DR, Carrington D. Peripheral blood lymphopenia and neutrophilia in children with severe respiratory syncytial virus disease. Pediatr Pulmonol 2002; 34: 128-30.

17. Chen RF, Chang JC, Yeh WT, Lee CH, Liu JW, Eng HL, Yang KD. Role of vascular cell adhesion molecules and leukocyte apoptosis in the lymphopenia and thrombocytopenia of patients with severe acute respiratory syndrome (SARS). Microbes Infect 2006; 8: 122-7.

18. Qu R, Ling Y, Zhang YH, Wei LY, Chen X, Li XM, Liu XY, Liu HM, Guo Z, Ren H, Wang Q. Platelet-to-lymphocyte ratio is associated with prognosis in patients with coronavirus disease-19. J Med Virol 2020; 92: 1533-41. 
19. Tay MZ, Poh CM, Rénia L, MacAry PA, Ng LFP. The trinity of COVID-19: immunity, inflammation and intervention. Nat Rev Immunol 2020; 20: 363-74.

20. Azkur AK, Akdis M, Azkur D, Sokolowska M, van de Veen W, Brüggen MC, O'Mahony L, Gao Y, Nadeau K, Akdis CA. Immune response to SARS-CoV-2 and mechanisms of immunopathological changes in COVID-19. Allergy 2020; 75: 1564-8.

21. Liu Y, Yang Y, Zhang C, Huang F, Wang F, Yuan J, Wang Z, Li J, Li J, Feng C, Zhang Z, Wang L, Peng L, Chen L, Qin Y, Zhao D, Tan S, Yin L, Xu J, Zhou C, Jiang C, Liu L. Clinical and biochemical indexes from 2019-nCoV infected patients linked to viral loads and lung injury. Sci China Life Sci 2020; 63: 364-74.

22. Tanaka T, Narazaki M, Kishimoto T. IL-6 in inflammation, immunity, and disease. Cold Spring Harb Perspect Biol 2014; 6 :16295.
23. Stüber F, Wrigge H, Schroeder S, Wetegrove S, Zinserling J, Hoeft A, Putensen C. Kinetic and reversibility of mechanical ventilation-associated pulmonary and systemic inflammatory response in patients with acute lung injury. Intensive Care Med 2002; 28: 834-41.

24. Parsons PE, Eisner MD, Thompson BT, Matthay MA, Ancukiewicz M, Bernard GR, Wheeler AP; NHLBI Acute Respiratory Distress Syndrome Clinical Trials Network. Lower tidal volume ventilation and plasma cytokine markers of inflammation in patients with acute lung injury. Crit Care Med 2005; 33:1-6.

25. Herold T, Jurinovic V, Arnreich C, Lipworth BJ, Hellmuth JC, von Bergwelt-Baildon M, Klein M, Weinberger T. Elevated levels of IL-6 and CRP predict the need for mechanical ventilation in COVID-19. J Allergy Clin Immunol 2020; 146 :128-36.

26. Gong J, Dong H, Xia Q, Huang Z, Wang D, Zhao Y, Liu W, Tu S, Zhang M, Wang Q, Lu F.

Correlation Analysis Between Disease Severity and Inflammation-related Parameters in Patients with COVID-19 Pneumonia. MedRxiv, 2020. 